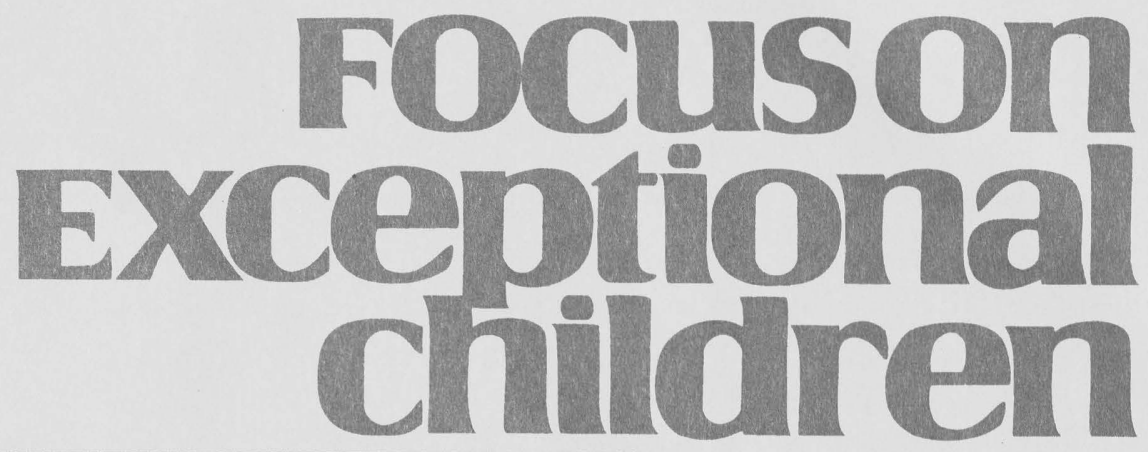

\title{
Framing the Progress of Collaborative Teacher Education
}

\author{
Cynthia C. Griffin and Marleen C. Pugach
}

Each of the 10 postulates in this article describes what we believe to be true about collaboration in special education. Each program description offers an important example of serious advancement toward collaborative programs in teacher education. Within this collective movement some programs can be placed at one end of a hypothetical continuum of development, and others at the other end. Despite these evolutionary differences, each program and each group of faculty has made significant steps toward programmatic reform in teacher education.

After considering what these programs have accomplished already, we thought about how they might be improved. We asked ourselves questions such as: Have these programs gone far enough? What areas haven't they addressed? Would differences in the nature of the process used to arrive at the new program have changed the outcome in any way? As we questioned certain features of the existing programs, we also thought about programs yet to be developed. We then generated sets of questions, starting on page 8 , which we hope will serve all of our readers as they work to strengthen existing collaborative programs and promote the development of new ones.

\section{POSTULATES}

We begin our list of postulates by answering the perhaps obvious question of whether collaboration in teacher education is achievable. Our previous discussion of the continuum of development suggests that it is. Further support for this, and the nine additional postulates, follow.

\section{Postulate One: Collaboration in teacher education is possible.}

More than a decade ago Allen-Meares and Pugach (1982) recognized that preparing preservice teachers in isolation from one another was a significant barrier to collaboration across disciplines. Today, many schools and colleges of education continue to deliver separate programs to prepare general educators, special educators, administrators, school psychologists, and school counselors. Although many barriers (e.g., lack of planning time, lack of knowledge about each other's discipline) can hinder successful collaboration, the information presented in this article show clearly that these barriers can be overcome. It can happen across disciplines and departments, within small arts and sciences colleges and

\footnotetext{
Marlene Pugach is a professor at the University of Wisconsin at Milwaukee. Cynthia Griffin is an associate professor at the University of Florida. This article was adapted from a chapter in the book Teacher Education in Transition (coauthored with Linda P. Blanton and Judith A. Winn), published by Love Publishing Company.
} 
large land-grant institutions, and among faculties who have very different philosophies of education. This diverse range of possible program characteristics appears in Table 1. The following example illustrates the ends of the continuum.

The collaborative teacher education program at Providence College is an example of a program developed at a small, private, liberal arts college. As the table shows, Providence College has 3,600 studerts. Eight faculty members serve the 370 students in the Education Department. In contrast, the University of Florida (UF) serves more than 38,000 students universitywide and 1,500 in the College of Education. Also taking into consideration the 18 tenure-line and grant-supported faculty members in the Department of Special Education and the 40 faculty members in the Department of Instruction and Curriculum (not to mention faculty members who represent three other departments in the college) at UF, the difference in the size of these two institutions is striking. The size and mission of each institution involved in teacher education reform has differential effects on the kinds of issues each one must resolve.

For example, at Providence the department had to deal with the tension that often exists in a liberal arts institution between faculty in the liberal arts and sciences programs and faculty in professional programs, particularly professional programs in education. The merged elementary/special education program had to be integrated with the liberal arts,

\section{FOCuson
Exceptional children}

ISSN 0015-511X FOCUS ON EXCEPTIONAL CHILDREN (USPS 203-360) is published monthly except June, July, and August as a service to teachers, special educators, curriculum specialists, administrators, and those concerned with the special education of exceptional children. This publication is annotated and indexed by the ERIC Clearinghouse on Handicapped and Gifted Children for publication in the monthly Current Index to Journals in Education (CIJE) and the quarterly index, Exceptional Children Education Resources (ECER). The full text of Focus on Exceptional Children is also available in the electronic versions of the Education Index. It is also available in microfilm from Serials Acquisitions, National Archive Publishing Company, P.O. Box 998, Ann Arbor, MI 48106-0998. Subscription rates: individual, $\$ 42$ per year; institutions, \$56 per year. Copyright (C) 2007, Love Publishing Company. All rights reserved. Reproduction in whole or part without written permission is prohibited. Printed in the United States of America. Periodical postage is paid at Denver, Colorado. POSTMASTER: Send address changes to:

Love Publishing Company

Executive and Editorial Office

P.O. Box 22353

Denver, Colorado 80222

Telephone (303) 221-7333

Carrie E. Watterson Editor
Stanley F. Love

Publisher 4-year curriculum. Discussions with the Education Department's planning team centered on what teachers should know and be able to do, and how to best include it within a minimum number of courses. These discussions were "lively, exhausting and painful." At UF, the faculty had to negotiate many meetings designed to seek official approval of the program in the departments of I \& $\mathrm{C}$ and SE. These meetings became challenging for the unified faculty because "consensus was difficult to achieve."

What is evident in these, as well as the other programs described in this article, is that even though collaboration was, and continues to be, complex, it can occur in teacher education if all parties involved realize that (a) change is a process, not an event (collaboration takes time); (b) anxiety, difficulties, and uncertainty are intrinsic to all successful change; and (c) reform must focus on the culture of the institution, as well as the structure, policy, and regulations inherent to the institution (Fullan \& Miles, 1992).

\section{Postulate Two: Collaborative programs can be initiated from many departure points.}

In the 10 programs described in this article, the stimuli for reform came from many sources and situations. At Utah State University, for example, development of the DualMajor Program was precipitated by new faculty hires, a move to a new building that placed the two departments in closer proximity to one another, and concerns expressed by some general education graduates who did not feel prepared adequately to teach students with learning and behavior problems. The University of Alabama had to contend with a loss of nearly "half a million dollars in permanent funds." This loss was the college's gain because it required that faculty reassess the nature of its work and reorganize teacher education in the college.

At Florida, external funding was a catalyst. These various stimuli often intersected with philosophical allegiances that moved reform ahead, often occurring simultaneously with new waves of faculty members. "Armed with the belief that it is our legal and moral obligation to educate all of our nation's youth," the faculty at Connecticut were poised to undertake "a radical reconceptualization about how teachers can best be prepared." At San Marcos, the opportunity to build a teacher education program from the ground up, without the "baggage" of a traditional institutional culture, meant that the faculty could forge ahead quickly.

In most of these cases, the communication, good will, and common ground necessary to develop collaborative teacher education programs took place across departments without changing the departmental structure. Within the traditional framework of separate departments, serious collaborative planning and programming have taken place. At the University of Wisconsin-Milwaukee, an explicit decision 


\section{TABLE 1 \\ Summary of Program Features (1999)}

\begin{tabular}{ll}
\hline Institution & Size \\
\hline University of & Tuscaloosa has a \\
Alabama & population of about \\
& 50,000 people; 20,000 \\
& students at Alabama; \\
& 2,300 in the College \\
& of Education
\end{tabular}

University of Cincinnati

University of Connecticut

University of Florida

University of WisconsinMilwaukee

California State University, San Marcos

Providence College

Saginaw Valley State University

Syracuse University

Located in rural Storrs; 24,000 students; 375 county; 3,000 students total; 300 in College of Education an urban community; 4-year, undergraduate Education

Located in Bay City, Michigan, 4-year state those in Education

Program

Cincinnati is located in an urban community; 35,000 students at UC; 2,500 in the College of Education students preparing to be teachers in any given year

Multiple Abilities Program (MAP), institutionalized; undergraduate

Institutionalized; 5-year undergraduate/graduate programs in Elementary, Secondary, and Early Childhood; 1-year graduate program (master's in Special Education)

Institutionalized; 5-year undergraduate/graduate; subject-area major in the liberal arts; cohorts of about 125 students per class

\section{Unified Early Childhood} Program, institutionalized, 5-year undergraduate/ graduate

\section{Urban Teacher Education} Program for Collaborative Communities, institutionalized, 4-year program with an optional 5 th year in Special Education

\section{Concurrent Credential}

Program, institutionalized, 4-year program

Providence is located in college of liberal arts and sciences; 3,600 students; 317 in the Department of institution; 7,300 students at the University; 1,300 of

Syracuse, New York is an urban community; undergraduate/graduate private institution; 14,000 students; 240 in the collaborative program

Located in Logan, Utah; undergraduate/graduate public institution; 20,000 students; 3,000 in Education
Merged Elementary/Special Education Program, institutionalized, 4-year program

Unified Elementary Pilot Program in Elementary and Special Education; pilot; 4-year undergraduate program

Inclusive Elementary and institutionalized; 4-year undergraduate program

Dual-Major Program in Elementary and Special Education; institutionalized; Special Education Program; 4-year undergraduate program

Certification

Multiple Abilities, K-6, which is equivalent to holding three certificates: Early Childhood, K-2; Elementary, 1-6; Mild Learning \& Behavior Disorders, K-6

Option A: Severe Behavior Disabilities \& SLD; Option B: Developmental \& Multiple Disabilities; Option C: Hearing Impairment; \& Option D: Early Childhood Special Education

State department traditional with special education certification being noncategorical PreK-12

Birth to age 4 preschool; age 3 to grade 3 PreK/primary; PreK Handicapped Endorsement (3-5 yr. olds with disabilities)

Early Childhood, ages birth-8; Primary/Middle, ages 6-14; Special Education certification in 5th year postbaccalaureate option

Concurrent Multiple Subjects (Elementary); Bilingual/Cross Cultural Language and Academic Development; Special Ed in Learning Handicapped (K-12)

Elementary Education; Special Education (mild/moderate disabilities)

Elementary (K-5); two areas in Math, Science, English or Soc. Studies (6-8); \& Learning Disabilities (K-8)

Elementary (PreK-6); Special Education (K-12)

Elementary (K-8); Special Education (K-12 in mild/ moderate)
Partnerships

Teachers helped design the MAP program; teacher mentors in MAP also serve as cooperating teachers to program students

Professional Practice Schools created by the Cincinnati Initiative, Cincinnati Public Schools, and the Cincinnati Federation of Teachers

All of students' clinical work over six semesters takes place in Professional Development Centers

Professional development efforts through faculty-cooperating teacher partnerships

Urban Professional Development Schools at the elementary level; courses taught at many school sites

College students take program courses taught at local schools; development of consortia with school districts

Professional Development Partnerships with two urban elementary schools

SVSU/BCE partnership composed of faculty, school staff, and parents

Professional Development Schools engage Syracuse-area public schools and the community in the teacher education process

Programmatic foundation in parent/ community involvement 
was made to turn away from changing the departmental structure as a goal in favor of more immediate programmatic reform. Although we cannot be certain whether progress might have been more efficient had departments been integrated, or whether departmental integration might be a logical, eventual outcome of collaborative programs, restructuring of departments was not the jumping-off point for reform.

\section{Postulate Three: Collaboration requires real time for communication.}

When we think about collaboration in teacher education, we must explore the role of communication simultaneously. Good communication is essential for good collaboration. 'The importance of preservice teachers' acquiring good communication and relationship skills has been strongly supported in the literature (Friend, 1984; Friend \& Cook, 1996; Pugach \& Johnson, 1995) but has not been modeled well in institutions of higher learning that, by nature, are competitive and individualistic. Teacher educators can start to develop communication skills and strategies that will assist them in developing and sustaining collaborative relationships. In the programs described here, this often began by engaging in philosophical discussions leading to a careful articulation of the philosophy and goals of the program.

At Syracuse University, for example, during informal discussions about what is now called the Inclusive Elementary and Special education program, the faculty drafted formative versions of a unified statement of purpose, an ongoing activity that it found helpful in articulating "shared values, principles, and practices that were a guiding force later as the program was implemented." Among the shared values identified were: inclusion and equity, teacher as decision maker, multiculturalism in education, innovations in education, and field-based emphasis. The University of Connecticut decided to express its program philosophy and goals in another way-through programmatic themes (Barnes, 1987; Howey \& Zimpher, 1989; Katz \& Raths, 1992; Kennedy, 1990; Pugach, 1992a). The themes of Reflection and Inquiry, and Diversity, were agreed upon and embedded into early discussions centered on program development, resulting eventually in co-authored articles and a co-authored book on reflective practice.

Having a clearly stated philosophical commitment and goals for the collaborative program were critical to the successful development and implementation of these two programs and were characteristic of other programs described in this article as well. Where such prior discussions did not take place-for example, at Utah State University-a byproduct of the dual-major program is that faculty members now are beginning to have these discussions across departments, after the fact.
Discussions that centered on program philosophy and programmatic themes served to gather faculty members around the table - many of whom had not engaged in such shared dialogue before. These discussions were designed to help faculty members trust that their commitments to certain principles would be represented in the shared beliefs they developed. In addition, these initial discussions about philosophy helped the faculty establish a climate of trust, explore alternative perspectives, define problems and issues, resolve conflicts, and use specific strategies that facilitate further communication (Friend, 1984). As trying as these conversations were, they formed the foundation for future work. At the University of Wisconsin-Milwaukee, the formal codification of a set of shared, core values was preceded by a period of informal collaborative conversation and interaction that made the eventual decisions somewhat smoother.

During the early stages of collaboration, the University of Cincinnati faculty asked an important question about communication within its own department: After years of maintaining separate programs of study in special education, how do faculty members begin a dialogue about core beliefs? Despite considerable barriers to communication (e.g., heavy instructional responsibilities, strong feelings of ownership to aspects of the old program), faculty members were able to begin discussions and learn how to talk with one another by building consensus around a set of shared principles.

Other techniques included sharing one-page interpretations, or response papers, to assist the faculty in thinking about a concept or idea (e.g., diversity, inclusion) between meetings. In addition, the entire college engaged in discussions about reform through cross-departmental committees that facilitated collegewide communication. Faculty representatives from one department attended meetings in another department with the mission of infusing issues and ideas important to their discipline into the conversation. For example, Special Education faculty members attended meetings in Elementary Education to bring up the idea that concepts related to special education should be infused into programs rather than presented in add-on courses of content taught by Special Education.

In general, communication takes time, and having time together is essential to collaboration and team building (Bondy, Ross, Sindelar \& Griffin, 1995) and to developing "a foundation of shared concern and a shared sense of purpose" (Rudduck, 1991, p. 97). It also involves a wide variety of constituents, or stakeholders, both internally and externally, including faculty, university students, deans, school teachers, school administrators, parents, and community members.

The "journey" in Cincinnati spanned a number of years, not days or weeks. Over time, the faculty attended many meetings. Some meetings were called to gather together small groups of like-minded people. Larger, more diverse 
groups were formed for other meetings, depending on the topic of discussion. Minutes were kept at meetings to provide a record of commitments and accomplishments. And proposals were drafted and circulated across colleges and schools for feedback and revisions.

Communicating with stakeholders external to institutions of higher education themselves was another source of ideas and was used to build support for change. At CSU San Marcos and Alabama, for example, teachers and administrators in the local area districts had major input into how the new programs would be conceptualized. Community forums at the University of Wisconsin-Milwaukee were places to share progress on program development with local constituencies. In many cases, external stakeholders came into play more in relationship to the field-based component of the programs (see Postulate Five).

The amount of time needed to accomplish shared communication and a shared set of values, goals, and expectations is extraordinary. Further, the time necessary for communication does not end once the program is initiated. At Milwaukee, for example, ongoing "conceptual discussions" are being woven into new, normative faculty practices in terms of program monitoring. At the same time, the challenge of finding the time seems to have been tempered by the stimulating character of the dialogue itself, the belief that this is a new and unique set of conversations, and the real progress resulting from the time invested.

\section{Postulate Four: Supportive leadership is essential.}

Before many of the reform efforts described in this article began, influential local leaders supported and promoted the concept of collaboration in teacher education. At Utah State University, the dean "publicly acknowledged and encouraged the collaborative efforts ... in the two departments through memos and through verbal notice at administrative council meetings." The dean at the University of Alabama created a task force charged with making "recommendations regarding preparation programs that . . . assist prospective teachers to develop appropriate attitudes and expertise in instructional strategies that (a) meet the needs of a wide range of students, (b) are child-centered rather than label-centered or programcentered, and (c) are collaborative in nature."

Change efforts require resources in addition to supportive leadership. Consequently, supportive leaders first must believe that collaboration creates benefits that offset added costs (Whetten, 1981), then work to provide professional development, new materials, and space, and above all, additional time. The need for more time requires leaders to reconfigure schedules and workloads creatively, and to find alternative sources of funding (Fullan \& Miles, 1992).

Although supportive and visionary leaders are important to help begin and sustain change efforts, several collaborative programs represented in this volume began with a core group of faculty, not administrators, who were committed to developing a collaborative program. Sometimes that core consisted of only two or three faculty members, as in Florida, Providence, Syracuse, and Connecticut. At others, such as Milwaukee, a larger group constituted the core. In all cases, faculty members were familiar with the calls from professional organizations and in the literature for unification and reform in teacher education, and they felt compelled to respond. The resourcefulness of deans and department chairs throughout the development continued to be critical, but in these cases the impetus for change came from visionary faculty members themselves.

\section{Postulate Five: New programs occur in conjunction with strong school partnerships.}

The 250 teacher preparation programs that are members of the Holmes Group are working to improve education in a number of ways. One significant way is through the creation of Professional Development Schools (PDSs) that foster partnerships between universities and public schools (Holmes Group, 1986, 1990). For many of these programs, the involvement in PDSs provides an opportunity for the simultaneous renewal of schools and teacher education. In her collection of seven case studies of newly emerging professional development schools, Darling-Hammond (1994), tells of both the successes (e.g., preparation and professional development of teachers) and challenges (e.g., lack of expansion of the PDS model into the rest of the school) facing these partnerships. Increased, intensive, field-based experiences are characteristic of most of the programs described here. Many have integrated their collaborative efforts directly with school partnerships, some designated as PDSs and others not desig,ated formally.

The University of Cincinnati's and Syracuse's memberships in the Holmes Group served as a catalyst for development of a system of PDSs in the Cincinnati and the Syracuse area public schools. These schools have become learning communities where adults (teachers, teacher educators, and administrators) and children learn continually (Holmes Group, 1990) and where all of these groups "are present and work together at the school site regularly" (Pugach \& Johnson, 1995, p. 202).

At the University of Cincinnati, special education faculty and school faculty members collaborate "to gain insight into the process of educating all children, to assist the schools in educational change activities, to encourage school faculties to become more inclusive in their practices, to engage in professional development activities, to model teaching practices, and to learn from faculty members who are implementing theory and providing daily guidance to the student interns." 
At Syracuse, students in their junior year become part of a Professional Development School cadre that remains together through the student teaching semester and graduation. Each cadre consists of 12 preservice teachers and 12 to 15 cooperating teachers (both general and special educators) from two or more schools, at least one urban and one suburban.

The Saginaw Valley State University (SVSU)/Bangor Central Elementary (BCE) School Partnership includes the College of Education faculty, the college dean, staff and administrators from the school and the district, and school parents. A key purpose of the partnership is to explore new ways of preparing teachers for inclusive and unified settings. Through this partnership the Unified Elementary Pilot Program was created. Program participants develop knowledge and skills in both special and elementary education, including competencies required of a classroom teacher in an inclusive setting. These students learn to practice inclusive education at BCE, where both university and school faculty model teaching and collaborative problem solving.

Another important outcome of the partnership between SVSU and BCE has been the development of professional development workshops for all parties involved. As expectations for professional collaboration grew, the need for professionål development increased as well (Lieberman \& Miller, 1991). For example, participants found themselves assuming new roles in the program, and at that point the need for staff development became, and continues to be, critical. Participants agreed upon a first set of workshops focusing on the topic of integrating course content (science education and content-area reading) in unified/inclusive settings.

Although the program at Alabama does not describe formalized relationships with specific schools, the intense nature of the field-based component is evident both in amount and structure. Teacher mentors are key to developing MAP students' skills, and MAP has also integrated a unique parent mentor component, specifically in relationship to the special education goals of the MAP program.

Dynamic relationships with area schools also characterize the Concurrent Program at CSU San Marcos. The new College of Education was developed specifically with strong school partnerships as a basic, underlying value, and a strong field-based component is integrated throughout the program. The notion of partnerships is enacted further through the Distinguished Teacher in Residence program, which institutionalizes the partnerships for the long term.

The partner schools that work with the University of Connecticut include 32 schools in parts of nine school districts, representing rural, suburban, and urban settings. These Professional Development Schools are places where colleagues from the schools and the university, with their respective students, come together to prepare future teachers and renew the teaching profession (including university teaching), and where there is shared dedication to the improvement of schools. At Connecticut, faculties from all departments in the School of Education, not just those in general and special education, are working in PDSs.

Where strong relationships with schools are not a part of the initial efforts, the need to develop such sites becomes apparent quickly. In the Unified program at Florida, the stark reality that few places existed where students in this program could play out the approaches they had learned, or view programs representing the unified early childhood philosophy, led to a subsequent emphasis on developing strong partnerships in the future.

\section{Postulate Six: It is possible to work with State Departments of Education.}

More often than not, state departments of education lead the way in deciding course requirements for certification. And these certification policies typically determine whether teacher education programs in special education are categorical or noncategorical (Lilly, 1992; McLaughlin, Valdivieso, Spence, \& Fuller, 1988). Despite the influence state departments of education seem to have on the design of teacher education programs, a number of programs described in this article were designed first and then taken to their respective state departments for review.

The University of Alabama submitted a proposal to its State Department of Education describing the Multiple Abilities Program (MAP). Subsequently it received a new certification area, Multiple Abilities Certification, K-6. The Multiple Abilities Certification wraps three certificates (Early Childhood, K-2; Elementary, 1-6; and Mild Learning and Behavior Disorders, K-6) into one.

The faculty at CSU San Marcos anticipated difficulties working with the California Commission on Teacher Credentialing (CTC) because of the "traditional separatist approach to certification in general and special education." Yet it proceeded with a presentation of its proposal for a new program. The faculty was surprised to receive "accolades for the forward-thinking approach to the program design" from the CTC. Students completing the collaborative program (the Concurrent Credential Program) at CSU receive full credentials in elementary education, special education (learning handicapped), and bilingual, cross-cultural education.

At SVSU, there was a reciprocal relationship between working on reform at the statewide level and local reform of the program. Faculty members who were involved directly in program reform also served on a state task force explicitly designed to address inclusive education. A natural link was formed between the task force recommendations, through SVSU faculty participation on the committee and discussions within the College of Education regarding the future of teacher preparation. 
In other cases, the teacher education programs had to side-step problems associated with state department requirements. For example, the titles of courses included in the merged program at Providence College reflect only what the state accreditation agency requires in the program coursework but did not represent the nature of the content included in those courses. What is important to note is that the incompatible certification structure at the state level does not seem to present an insurmountable obstacle. The program faculty may push for new credentialing structures or may re-create programs under existing course titles. In either case, the goal of reform seems within reach.

\section{Postulate Seven: Even if some people do not buy into the changes, progress can be made.}

The University of Connecticut claims to have two special education departments! One consists of faculty members who have bought into the integrated teacher preparation program, and the other consists of a small group whose members believe their role is to serve as a graduate research faculty or provide categorical programs of study for special education teachers. This second group of faculty has refused to support the new teacher education program. Despite this bifurcation, significant progress toward program development and implementation has occurred. One might ask how this could happen.

Fullan (1991) may respond that not all people, or even most people, should be expected to change. Change involves such a complex interplay of forces that reforming a large social institution such as a school or college of education may seem almost impossible. Despite this, progress does occur, and it occurs in steps that serve to increase the number of people who are affected. For example, the success of the MAP effort conducted by a handful of faculty members at Alabama led to a larger conversation regarding the structure of other programs. Instead of being discouraged by naysayers, Fullan suggests that reformers concentrate on their accomplishments. Faced with resistance, the core reform faculty in many of the 10 institutions included in this article propelled themselves forward by celebrating their achievements and continuing the communication despite apparent or real resistance.

\section{Postulate Eight: Evaluation is an important component of program development.}

Determining the success of collaborative programs requires, at a minimum, an examination of (a) outcomes and (b) the satisfaction program participants feel before and after graduation (Friend \& Cook, 1996). Many of the collaborative programs include an evaluation component, particularly in the area of participant, or consumer, satisfaction. The University of Connecticut has a system of program evaluation consisting of surveys, interviews, focus groups, observations, focused discussions, and field notes, among other methods. Evaluation has been conducted for accreditation purposes, programmatic review, and modification of program elements. Master's- and doctoral-level research has focused on program evaluation, and the findings have served to change or alter elements of the program and have been disseminated widely.

Through the use of telephone interviews, Utah State University asked the first graduating class of dual-major program graduates what motivated them to enroll in the program, what they saw as similarities and differences across the elementary and special education programs, how they dealt with the differing perspectives offered in each of the programs, and how well prepared they thought they were for their first year of teaching. Of the eight graduates surveyed, three were elementary teachers, three were special education teachers, one was teaching both elementary and special education, and one was not teaching.

The University of Cincinnati takes a four-pronged approach to evaluation. Students evaluate courses, a cohort group of school and university-based faculty members evaluate course syllabi, student teachers and PDS faculty evaluate the relationship between courses and the demands of the internship, and graduates of the program are surveyed each year. In addition, a system of feedback is structured around discussions that lead to shared problem solving.

The data collected across collaborative programs reflect many positive comments from graduates and from the constituent groups that have worked with and employed these graduates. Selected comments suggest that districts seek these graduates; they are confident first-year teachers; they are committed to the principle that all children can learn; they are aware of the multifaceted needs of children and youth; and they are mastering the practices of collaboration and individualization.

\section{Postulate Nine: Collaborative programs can be responsive to the community surrounding the university/college.}

Teacher education programs traditionally have sustained a separation of spheres between school and home/community. Consequently, no clear model or established tradition of learning in community exists (de Acosta, 1996, p. 13). As de Costa relates, teacher education programs have not responded well to issues of community, or to the impact the community has on children's learning. She recommends community placement for preservice teachers to help them develop "relationships that support caring and trust," understand "what social and cultural capital is available," and learn how to select and use "family involvement models and practices" (p. 13). 
In a few cases, the importance of community is made explicit in the nature of the coursework and the design of the experiences students receive in the collaborative program. Both Syracuse University and the University of Connecticut place students in PDS schools located in urban, suburban, and rural settings. The focus on urban field placements for students in the Collaborative Teacher Education Program for Urban Communities drives the work at the University of Wisconsin-Milwaukee. The emphasis on multicultural communities is evident in the coursework leading to the Bilingual Cross Cultural Language and Academic Development credential that is part of the certification package offered at CSU San Marcos, as well as the Multicultural Issues course that is a part of the Unified Early Childhood program at the University of Florida.

\section{Postulate Ten: Collaboration forces a confrontation with new or alternative conceptions of teaching and learning.}

Whether faculty members engage in a priori philosophical discussions of their beliefs about teaching and learning, or whether the conversations emerge during the implementation phase of collaborative programs, their proximity and interaction set the stage for a confrontation with different ideas and practices about teaching and learning. This simply does not occur in isolation. Today, for example, terms such as constructivism, apprenticeship learning, learning communities, meaningful activities, authentic assessment, classroom dialogue, responsive instruction, and socially shared cognition (Leinhardt, 1992) represent concepts that teacher educators in general education value and are quite familiar with.

For example, with few exceptions (e.g., Englert, 1992; Montague, 1992; Palincsar \& Klenk, 1992), special education has been slower to embrace a social constructivist perspective in which teaching and learning are viewed as highly complex. This approach requires a teacher to operate in an ever changing context of decision making that goes beyond narrow assumptions of teaching and learning as the transmission of information (Merseth, 1992). For special education, collaborative efforts to prepare teachers have brought faculty members into close contact with their general education colleagues and forced a meeting with these alternative conceptions. In this way, it becomes more difficult to reject such approaches outright as inappropriate for children and youth with disabilities and pushes faculties to reconsider the predominantly behaviorist tradition in special education. Likewise, it should promote a real consideration of which specific aspects of behavioral practice might be useful to all teachers.

In a number of the programs described in this article, themes, activities, and assignments typify a social constructivist view of teaching and learning. For example, at the University of Florida, Unified Early Childhood students reflect on their interactions with young children by conducting semester-long action research projects. These projects allow pairs of students to explore, in more depth, questions that surfaced during their student internships. At CSU San Mar$\cos$, the "deemphasis on overt error correction and discrete skills instruction and the emphasis on meaning ... and cooperative and flexible groupings," as well as the development of risk-free environments for children, are infused throughout the coursework. Use of the ecological case study in the Concurrent program also provides students with the opportunity to observe, interview, and report on a child.

The emphasis on reflective teaching, facilitative learning, and authentic assessment and instruction in the MAP Program at the University of Alabama provides yet another example of how conceptions of teaching and learning have changed as new collaborative programs are developed. A "reflective mindset" is fostered in MAP students through weekly journal entries that reflect students' philosophies and assumptions about teaching and learning. The MAP faculty responds to students' entries in an attempt to help them examine their past and current experiences in ways that respect diversity and are empowering to children.

Syracuse's emphasis on the role of the teacher as reflective practitioner in the program goal areas is another example. Within this role, the teacher is viewed as a learner, an inquirer, and a problem solver. In the program goal area of curriculum, faculty members model a thematic approach that is both inquiry-based and community-based. And at the University of Wisconsin-Milwaukee, the Professional Urban Linking Seminar is designed to promote a holistic understanding of the programmatic values, themes, and practices in the challenging context of urban schools. Left isolated, many teacher education programs in special education might not consider the importance of linking the components of a program.

These teaching and learning activities it represents are not the last new developments to come along and challenge the practice of teaching and teacher education. For example, some things about social constructivism may outlast its faddish nature, just as things about behaviorism should be taken seriously. The point is that when teacher educators do their work together regularly, they can no longer retreat handily into their prior practices. Public conversation and the public practice of teacher education seem to result in richer conceptions of teaching and learning and a much faster integration of more complex, more contemporary modes of education in schools and colleges of education. This, ultimately, is one of the most important developments in collaborative teacher education.

\section{FROM POSTULATES TO CRITICAL QUESTIONS}

Let us say unequivocally that the 10 programs described in this article indicate the depth of change possible when a 
faculty decides to address the question of who it is we expect all teachers to teach. Faculties in these programs have managed, through hard work, will, and strong intellectual commitment, to begin to bridge the gulfs that in many ways are institutionalized in higher education. This is no small feat, and as teacher educators, we all need to acknowledge the strides these programs illustrate in breaking down the longstanding barriers that have mitigated interdependence in teacher education for so long. More important, faculties have come together to define what they believe to be a shared base of knowledge for all teachers. Although this is not a new goal (Reynolds began calling for the same thing as early as 1980), this is, to our knowledge, the first time such productive conversations have taken place between special and general education on a more than incidental scale-dispersed widely geographically and among different kinds of institutions of higher education.

The processes and programs described here exemplify many of the benefits gained when teacher educators, administrators, the school faculty and staff, parents, and communities work together toward the goal of nurturing and teaching all children and youth. Despite the magnitude of progress to date, as we analyze the gains made, we also have identified four issues that are unresolved yet crucial to the eventual success of teacher education that is committed to preparing its graduates to work most effectively with all students. The progress achieved thus far has opened a window onto a deeper set of questions, questions that stretch beyond the commitment to the common framework these teacher education programs have achieved already. How is special education defined? How are special education and diversity related? What is the role of faculty development in reforming and supporting the development of teacher education? What is the role of program evaluation? We turn now to an analysis of these unresolved issues. We hope these questions will push those who already are collaborating and those who are interested in establishing new collaborative teacher education even further in their thinking about some of the most challenging issues regarding what it means to prepare teachers to work with and meet the needs of all children and youth.

\section{How Will We Define Special Education?}

In most of the programs reported here, the impetus for collaboration was finding the commonalties between special and general education. To achieve collaboration, one of the first things the faculties in these programs did was to find their points of convergence. Placing the child at the center of the deliberations, many faculty members were able to transcend longheld assumptions about what special or general educators believe, how narrow or broadminded they may be, or whether they really are diehard behaviorists or rampant humanists. Indeed, some degree of compatibility was found to exist. Some began from ground zero, and others used existing programs as departure point.

At one end of the continuum, Alabama and SVSU began with existing competencies and placed them in a more unified structure. At the other end, at Connecticut and Milwaukee, debate regarding commonalties drove programmatic change. At Cincinnati, uncovering the commonalties among special education faculty members themselves was considered to be a critical first step in defining its contribution to the preparation of general educators. In the program at Utah State, questions of commonalty among faculty members are only beginning to emerge after substantial experience with a dual-certification program that explicitly rejected this task initially as unproductive.

In reaching agreement at varying levels, the roles of special and general educators in these programs often are described as interchangeable, overlapping, or unified. This terminology suggests a common commitment to children on the part of all teachers and the common ownership of all students-a situation that differs markedly from traditional educational practice in the schools and in institutions of higher education. Whether they are prepared in a unified program at Syracuse, an experimental program at Alabama or SVSU, or a dual-certification program at Providence or Utah, preservice teachers who complete them are prepared explicitly for a commitment to accepting all children as full members in their classrooms. In this way, the goal of access - of who belongs in general education classes, of having teachers who are not willing simply to reject or marginalize students-is well served by each of these 10 programs. Even so, are access and interchangeable teacher roles in and of themselves sufficient goals for collaborative programs of teacher education, or is more at issue here?

Those who are wary of bringing special and general education together and engaging in collaborative teaching or teacher education often begin by posing the question, "What's special about special education?" (e.g., Zigmond, 1995). They begin by seeking to identify the differences between special and general education. The history of the relationship between special and general education has presented problems, however, precisely because we have failed, time and time again, to find our common ground. We have allowed difference to dominate and have looked at education as an "either-or" proposition: Either we operate from a large-group perspective or we provide for individual instruction, but one system can't seem to include both. We have not been able to conduct our work from a conceptual framework that makes a place for both classwide community building and learning - the hallmarks of general education-and effective models of intensive instruction-the purpose of special (and much of remedial) education (Pugach, 1995; Pugach \& Seidl, 1996). 
By first asking the question "How are we alike?" the professionals in these teacher education programs have been successful in beginning to establish that common framework. In the case of Florida, the commitment to developmentally appropriate practice is what formed the unifying framework and enabled the early childhood faculty to go beyond the traditional behaviorist/humanist split. In the case of CSU San Marcos, it is the capacity to provide strong general education experiences to children who are excluded inappropriately for a variety of reasons, including language or disability. At Milwaukee, the press of the urban environment frames common values. Empowerment underlies the MAP work at Alabama. At Providence College, collaboration itself provides the framework. Even in the absence of unifying themes, the student at Utah State who begins to grasp that direct instruction has a place within a whole-language approach is moving toward a larger, more complex unifying framework.

These are monumental changes. And they begin to address one of the most problematic aspects of special education: how to move teachers beyond the practice of overlabeling students and passing off responsibility for them to special education teachers alone. But few of these programs then have taken what we see to be a complementary stepthat is, to identify what a special cadre of teachers might provide in schools. For example, many students need intensive instruction in the area of literacy, and special education's traditional approach of decontextualized basic skills instruction has not been successful. How will such intensive instruction be defined and carried out, and by whom?

These kinds of questions challenge us to consider whether we are really comfortable with teacher roles that are completely interchangeable and see this as an endpoint for collaborative teacher education, or whether special (or other named) educators should be expected to provide specific things that general educators-however well prepared and however willing they may be to work with children with disabilities - should not be expected to provide. One of the greatest challenges we see to the success of collaborative teacher education is being able to define and then integrate what various teachers have in common and what they do not have in common in redesigning teacher education.

This is not a simple challenge, because what we do not have in common - that is, what constitutes special education-has to be completely redefined in relationship to the common framework these programs have established. It is not just a matter of adding what special educators always have done onto the monumental agreements these programs have achieved. That is not progress. Instead, program faculties have to engage in substantive dialogue about the differences in much the same way they have engaged in dialogue about the similarities. From the array of programs here, this corollary activity seems to have occurred infrequently. This piece of the collaborative teacher education puzzle demands that special and general education faculties alike question their own prior beliefs and assumptions and keep at the forefront of the conversation the balance between what can be achieved in the best of classrooms with the most inclusive of teachers, and what reasonably will have to be carried out as intensive instructional support in those same, exemplary classrooms.

From a political perspective, to suggest an upfront consideration of difference is risky when in so many institutions of higher education what is common in the preparation of teachers has yet to be explored. In the current climate of often hostile debates about inclusion, it would be easy to draw up sides with people lining up along traditional inclusion/anti-inclusion lines in a discussion of difference. What the programs described here have demonstrated so well is that this kind of rancorous interaction can be overcomewith deliberate and ongoing opportunities for serious dialogue about what is best for all children in schools.

\section{How Appropriate is the Diversity Umbrella?}

Almost without exception, one of the strongest stimuli for creating these, and many other, collaborative teacher education programs is to meet the increasing diversity of the school-going population. Diversity spans disability, class, race, and gender for MAP students at Alabama. At Florida, students are to prepare curriculum "for all children, including children with disabilities and diverse cultural backgrounds." The new teacher in Michigan is to meet the needs of "expanding diversity" (SVSU). Nearly every program we included situated its collaborative efforts in a larger context of diversity.

Students with disabilities are part of the fabric of our diverse student populations. Special educators are particularly sensitive to issues of access and participation, and rightfully so. By linking diversity and disability, special educators bring their concerns about equity and access under a broader and well established umbrella in education as we move into the next millennium. Diversity is posed as a point of commonalty, and diversity and disability are linked readily throughout the descriptions of these programs.

As argued elsewhere (Artiles \& Trent, 1994; Ball \& Harry, 1993), however, diversity and disability do not constitute an exact parallel. Diversity, as represented in the multicultural literature, is grounded in a sociocultural view of schooling, teaching, and learning. These sociocultural phenomena operate whether a child does or does not have a disability. If we are to understand disability in relationship to diversity, we have to be able to understand children through this sociocultural screen (Pugach \& Seidl, 1996).

Collaborative teacher education programs based on a desire to pair diversity and disability have to incorporate a strong, carefully grounded, high-level multicultural component. 
Otherwise this complex relationship between diversity and disability is likely to go unexplored. In the worst-case scenario, program graduates might talk about disability as another aspect of diversity, yet not be able to talk wisely about or understand why, for example, the overrepresentation of black males continues in special education. On the whole, special educators have not been forthcoming in discussing issues of diversity in their literature (Gottlieb, Alter, Gottlieb, \& Wishner, 1994; Pugach, 1995; Pugach \& Seidl, 1996). Although teacher educators in general education also are struggling with how to address diversity most effectively, the issue there is part of a much more public agenda.

The point is that just because collaborative programs are described as meeting the diverse needs of all learners, we cannot take for granted that its graduates, or its faculty, have a clear understanding of diversity in all of its cultural, linguistic, racial, ethnic, and socioeconomic complexity-in addition to considerations of disability. Some of the programs in this article include strong multicultural components. Others do not. Yet the latter often still ground their work in the language of diversity. Early on, the faculty at Providence understood that dealing with diversity from a typical special education perspective-namely, "through the accommodation of individual differences" - did not adequately address issues of cultural, racial, and linguistic diversity and sought a new, more appropriate, and complex understanding of disability and diversity.

If the trend toward collaborative teacher education is to move us beyond our longstanding conceptions of who does and does not belong in general education, our understanding of diversity itself has to move beyond appending disability concerns to a perhaps narrow idea of what diversity is all about. Developing collaborative teacher education programs represents a limitless opportunity to bring together faculties across special and general education to grapple with, and begin to come to terms with, this difficult and challenging issue.

\section{What is the Role of Faculty Development?}

The critical need for professional development becomes apparent rather quickly as faculty are absorbed in activities such as team-teaching and developing new content in a redesigned program. In the programs described here, professional development is fostered in significant ways, through the: (a) Professional Development Schools (PDSs) that have been cultivated at Cincinnati, Connecticut, and Syracuse; (b) lengthy and frequent conversations many faculty members have had about their programs; and (c) collaborative inservice presentations and co-authored publications and grants developed at Connecticut and Florida. Despite these efforts, few programs have addressed professional development directly or concretely. We believe teacher educators, particularly teacher educators working in collaborative programs where professional growth is crucial, must articulate a conscious commitment to on-going professional development for faculty. Teachers must become, in Fullan's (1991) words, "simultaneously and seamlessly inquiry oriented, skilled, reflective, and collaborative professionals," and if they don't, "educational reform will never amount to anything" (p. 326). This established link between continuous professional development and programmatic and institutional improvement suggests that teacher educators must continue to learn, or collaborative teacher education never will become a reality.

Achieving the aim of continuous learning as a valued and integral part of the college culture is not easy, but it is necessary if we hope to answer critical questions asked by teacher educators involved in the redesign of their programs. Questions such as, "How do we come to agreement on what we believe?" and "What do we mean by terms like 'diversity,' 'disability,' and 'special education'?" cannot be answered well if we approach professional development sporadically, without the benefit of follow-up or the attention to individual needs and concerns and site-specific issues (Hall \& Hord, 1987). We must create a long-term plan for our own professional development efforts, and these efforts should be incorporated into as many activities as possible. Our goal is to create new habits and structures, as opposed to developing isolated policies and practices.

\section{How Important Is Program Evaluation?}

Traditionally, teacher educators have conducted program evaluations with follow-up studies of recent graduates and of their supervisors (Raths, 1987) and outcome studies of graduates' teaching competencies (Galluzzo \& Craig, 1990). These established practices, however, have been criticized primarily for not providing data needed for meaningful program renewal (Katz, Raths, Mohanty, Kurachi, \& Irving, 1981). Findings from follow-up studies tend to be too generic, and outcome studies do not draw on the graduates' perspectives, only the judgments others have of their performance. Most of the programs described here did not evaluate their programs in ways that went beyond traditional practices.

Current evaluation efforts must be ongoing, interactive, both short- and long-term, and employ multiple methods. Only then will we be able to address questions such as, "How will growth in attitudes, beliefs, values, knowledge, and skill, as well as graduates' socialization into the profession, be documented?" and "How do teacher educators assess these indicators in ways that assist them in improving their programs?" In summary, these questions and the three previous sets represent an extended challenge to existing collaborative teacher education programs and make the challenge for new partnerships more complex. 


\section{Focuson Exceptional children}

\section{CONCLUDING COMMENTS, OR CAUTIOUS OPTIMISM FOR COLLABORATIVE TEACHER EDUCATION}

The 10 programs presented here attest to the reality that we can make real progress in teacher education and not hide behind old ways. We applaud the collaborative programs and the people working in them for their vision, determination, and skill. With sincere respect for their efforts, we conclude with one more question, one we hope will invite one last reflection.

Reform in teacher education has to be real, not cosmetic. To be authentic, conversations must take place in great depth, accompanied by serious joint reflection on the practice of teacher education. An important question to consider is whether we have been using the term "collaboration" too glibly. If the conversation between teacher educators in special and general education is not directed to the most difficult issues-for example, issues of equity, or fundamental shifts in curriculum and instruction-collaborative efforts will be surface-level and short-term. To be enduring, the most pressing needs of children and youth must drive our efforts. The cases presented here reflect a strong sense of commitment, convincing us that the hard dynamics that collaboration requires will continue to occur and that their example will encourage others to work as earnestly.

\section{REFERENCES}

Allen-Meares, P., \& Pugach, M. (1982). Facilitating interdisciplinary collaboration on behalf of handicapped children and youth. Teacher Education and Special Education, 5, 30-36.

Artiles, A. J., \& Trent, S. C. (1994). Overrepresentation of minority students in special education: A continuing debate. Journal of Special Education, 27, 410-437.

Ball, E. W., \& Harry, B. (1993). Multicultural education and special education: Parallels, divergences, and intersections. Educational Forum, 57, 430-436.

Barnes, H. L. (1987). The conceptual basis for thematic teacher education programs. Journal of Teacher Education, 5(4), 56-60.

Bondy, E., Ross, D. D., Sindelar, P. T., \& Griffin, C. (1995). Elementary and special educators learning to work together: Team building processes. Teacher Education and Special Education, 18(2), 91-102.

Darling-Hammond, L. (1994). Professional development schools: Schools for developing a profession. New York: Teacher College Press.

de Acosta, M. (1996). A foundational approach to preparing teachers for family and community involvement in children's education. Journal of Teacher Education, 47(1), 9-15.

Englert, C. S. (1992). Writing instruction from a sociocultural perspective: The holistic, dialogic, and social enterprise. Journal of Learning Disabilities, 25(3), 153-172.

Friend, M. (1984). Consultation skills for resource teachers. Learning Disability Quarterly, 7, 246-250.

Friend, M., \& Cook, L. (1996). Interactions: Collaboration skills for school professionals ( $2 \mathrm{~d}$ ed.). White Plains, NY: Longman.

Fullan, M. G. (1991). The new meaning of educational change ( $2 \mathrm{~d}$ ed.). New York: Teachers College Press.

Fullan, M. G., \& Miles, M. B. (1992). Getting reform right: What works and what doesn't. Phi Delta Kappan, 73(10), 745-752.

Galluzzo, G. R., \& Craig, J. R. (1990). Evaluation of preservice teacher education programs. In W. R. Houston, M. Haberman, \& J. Sikula
(Eds.), Handbook of research on teacher education (pp. 599-616). New York: Macmillan.

Gottlieb, J., Alter, M., Gottlieb, B. W., \& Wishner, J. (1994). Special education in urban America: It's not justifiable for many. Journal of Special Education, 27, 453-465.

Hall, G. E., \& Hord, S. (1987). Change in schools: Facilitating the process. Albany: State University of New York Press.

Holmes Group. (1986). Tomorrow's teachers: A report of the Holmes Group. East Lansing, MI: Author.

Holmes Group. (1990). Tomorrow's schools: Principles for the design of professional development schools. East Lansing, MI: Author.

Howey, K. R., \& Zimpher, N. L. (1989). Profiles of preservice teacher education: Inquiry into the nature of programs. Albany, NY: State University of New York Press.

Katz, L. G., \& Raths, J. (1992). Six dilemmas in teacher education. Journal of Teacher Education, 43, 376-385.

Katz, L., Raths, J., Mohanty, C., Kurachi, A., \& Irving, J. (1981). Followup studies: Are they really worth the trouble? Journal of Teacher Education, 32(2), 18-24.

Kennedy, M. M. (1990). Choosing a goal for professional education. In W. R. Houston (Ed.), Handbook for research on teacher education (pp. 813-825). New York: Macmillan.

Leinhardt, G. (1992). What research on learning tells us about teaching. Educational Leadership, 49(7), 20-25.

Lieberman, A., \& Miller, L. (Eds.). (1991). Staff development for education in the '90s (2d ed.). New York: Teachers College Press.

Lilly, M. S. (1992). Research on teacher licensure and state approval of teacher education programs. Teacher Education and Special Education, 15(2), 148-160.

McLaughlin, M. J., Valdivieso, C. H., Spence, K. L., \& Fuller, B. C. (1988). Special education teacher preparation: A synthesis of four research studies. Exceptional Children, 55, 215-221.

Merseth, K. K. (1992). Cases for decision making in teacher education. In J. H. Shulman (Ed.), Case methods in teacher education (pp. 50-63). New York: Teachers College Press.

Montague, M. (1992). The effects of cognitive and metacognitive strategy instruction on the mathematical problem solving of middle school students with learning disabilities. Journal of Learning Disabilities, 25(4), 230-248.

Palincsar, A. S., \& Klenk, L. (1992) Fostering literacy learning in supportive contexts. Journal of Learning Disabilities, 25(4), 211-225.

Pugach, M. C. (1992). Unifying the preservice preparation of teachers. In W. Stainback \& S. Stainback (Eds.), Controversial issues confronting special education: Divergent perspectives (pp. 255-270). Needham Heights, MA: Allyn \& Bacon.

Pugach, M. C. (1995). Twice victims: The struggle to educate children in urban schools and the reform of special education and Chapter 1. In M. C. Wang \& M. C. Reynolds (Eds.), Making a difference for students at risk: Trends and alternatives (pp. 27-60). Thousand Oaks, CA: Corwin Press.

Pugach, M. C., \& Johnson, L. J. (1995). Collaborative practitioners, collaborative schools. Denver: Love Publishing.

Pugach, M. C., \& Seidl, B. L. (1996). Deconstructing the diversity-disability connection. Contemporary Education, 68(1).

Raths, J. D. (1987). An alternative view of the evaluation of teacher education programs. In M. Haberman \& J. M. Backus (Eds.), Advances in teacher education (Vol. 3, pp. 202-217). Norwood, NJ: Ablex.

Reynolds, M. P. (1980, April). A common body of practice for teachers: The challenge of Public Law 94-142 to teacher education. Washington, DC: National Support Systems Project, University of Minnesota, and American Association of Colleges for Teacher Education.

Rudduck, J. (1991). Innovation and change. Bristol, PA: Open University Press.

Whetten, D. (1981). International relations: A review of the field. Journal of Higher Education, 5(1), 1-28.

Zigmond, N. (1995). An exploration of the meaning and practice of special education in the context of full inclusion of students with learning disabilities. Journal of Special Education, 29, 109-115. 